\title{
KONEKSI MATEMATIS PADA KONSEP EKONOMI (PERMINTAAN DAN PENAWARAN)
}

Ai Tusi Fatimah1, Adang Effendi², Asep Amam³

1,2,3 Program Studi Pendidikan Matematika, Fakultas Keguruan dan IImu Pendidikan

Universitas Galuh Ciamis

Email: tusifatimah@unigal.ac.id

Dikirim: 31 Januari 2018; Diterima: 28 Februari 2018; Dipublikasikan: 31 Maret 2018

\begin{abstract}
ABSTRAK
Matematika sebagai ilmu yang terstruktur dan saling berhubungan dapat digunakan untuk membangun suatu konsep pada bidang ilmu di luar matematika, salah satunya pada bidang ekonomi yaitu konsep permintaan dan penawaran. Penelitian ini bertujuan untuk mengetahui koneksi matematis pada konsep permintaan dan penawaran. Metode yang digunakan dalam penelitian ini adalah eksploratif. Hasil penelitian yang diperoleh: (1) koneksi fungsi permintaan dan penawaran dengan persamaan linear dua variabel atau fungsi linear yang dibangun dari berbagai ide matematika, (2) penggunaan masalah permintaan dan penawaran pada konsep peluang dan sistem persamaan linear dua variabel.
\end{abstract}

Kata Kunci: Koneksi Matematis, Permintaan, Penawaran

Cara sitasi: Fatimah, A. T., Effendi, A., dan Amam, A. 2018. Koneksi Matematis pada Konsep Ekonomi (Permintaan dan Penawaran). Teorema: Teori dan Riset Matematika Vol 2, No 2 (2018). Hal 107-116 


\section{PENDAHULUAN}

Matematika merupakan mata pelajaran yang memiliki standar serta wajib dipelajari di setiap jenjang pendidikan di sekolah. Standar isi dan proses pembelajaran matematika di setiap jenjang kelas tentunya berbeda-beda. NCTM (2000) mengklasifikasikannya ke dalam beberapa kelas yaitu pra kelas 2, kelas 3-5, kelas 6-8, dan kelas 9-12. Standar isi terdiri dari bilangan dan operasinya, aljabar, geometri, pengukuran, analisis data serta peluang. Standar proses terdiri dari pemecahan masalah, penalaran dan pembuktian, komunikasi, koneksi serta representasi. Semua standar tersebut merupakan satu kesatuan yang saling berkesinambungan di setiap jenjang kelasnya.

Afgani (2011) menyatakan bahwa koneksi matematis didasarkan pada matematika sebagai ilmu yang terstruktur dan terdiri dari bagian-bagian yang saling berhubungan. Dalam proses pembelajaran matematika, koneksi matematis perlu dilakukan di semua tingkatan kelas sehingga peserta didik dapat membangun pengetahuan matematika secara utuh. Standar koneksi matematis berdasarkan NCTM (2000) adalah mengenali dan menggunakan koneksi antar ide matematika, memahami bagaimana ide matematika saling berhubungan dan saling membangun untuk menghasilkan keseluruhan yang koheren, serta mengenali dan menerapkan matematika dalam konteks di luar matematika.

Penerapan matematika dalam konteks di luar matematika (bidang ilmu lain atau kehidupan sehari-hari) sering tidak disadari dan dikenali oleh peserta didik. Padahal, dengan mengenali penerapan matematika akan menjadikan pembelajaran matematika lebih bermakna. Salah satu kompetensi lulusan mata pelajaran matematika adalah supaya konsep matematika dapat diterapkan dalam kehidupan sehari-hari (Kemendikbud, 2016). Lebih jauh lagi, jika peserta didik dapat mengenali penerapan matematika dalam bidang yang diminati maka pemahaman konsep-konsep matematika akan lebih mudah dilakukan.

Peserta didik yang memasuki jenjang sekolah menengah tingkat atas akan memilih bidang keilmuan yang diminatinya. Salah satu peminatan di sekolah menengah atas (SMA) adalah ilmu sosial yang di dalamnya terdapat mata pelajaran ekonomi. Pelajaran ini memiliki beberapa konsep yang memerlukan matematika sebagai landasannya. Di antara konsep tersebut adalah konsep permintaan dan penawaran. Konsep ini dipelajari di kelas $\mathrm{X}$.

Konsep permintaan dan penawaran merupakan konsep dasar dalam ilmu ekonomi (Widjajanta dan Widyaningsih, 2009). Permintaan (demand) adalah banyaknya jumlah barang yang diminta pada suatu pasar dengan tingkat harga, tingkat pendapatan, dan periode tertentu. Sedangkan penawaran (supply) adalah banyaknya barang yang ditawarkan oleh penjual pada suatu pasar dalam suatu periode dan tingkat harga tertentu. Permintaan dan penawaran dapat dipengaruhi harga, dan sebaliknya. Harga dan banyaknya suatu barang yang diperjualbelikan dapat ditentukan dengan melihat keseimbangan antara permintaan dan penawaran di suatu pasar (Eko, 2009).

Berdasarkan pernyataan pengertian konsep permintaan dan penawaran, maka terdapat beberapa variabel. Variabel adalah simbol atau lambang yang digunakan untuk merepresentasikan suatu nilai (Bailey, et al, 2006). Dalam konsep ekonomi, banyaknya permintaan, atau banyaknya penawaran dilambangkan dengan variabel $Q$, sedangkan harga barang dilambangkan dengan variabel $P$. Variabel-variabel tersebut saling berkaitan dan dapat direpresentasikan dalam bentukbentuk ekspresi aljabar, persamaan atau fungsi. Suatu ekspresi aljabar terdiri dari variabel, bilangan, dan paling sedikit satu operasi. Contoh sebuah ekspresi aljabar adalah $2 P$; terdiri dari bilangan 2 , variabel $P$, dan operasi perkalian. Jika variabel $P$ diganti dengan 1000 maka ekspresi aljabar $2 P$ berubah menjadi $2 \times 1000$ dan disebut ekspresi numerik. Hubungan antara banyaknya permintaan dengan tingkat harga barang akan membentuk suatu persamaan matematis yang lebih dikenal

Cara sitasi: Fatimah, A. T., Effendi, A., dan Amam, A. 2018. Koneksi Matematis pada Konsep Ekonomi (Permintaan dan Penawaran). Teorema: Teori dan Riset Matematika Vol 2, No 2 (2018). Hal 107-116 
dengan fungsi permintaan, sedangkan hubungan antara banyaknya penawaran dengan tingkat harga barang akan membentuk persamaan matematis yang lebih dikenal dengan fungsi penawaran.

Fungsi permintaan dan penawaran dapat dibangun dengan mengoneksikan konsep-konsep matematika. Oleh karena itu, penelitian ini bertujuan untuk mengetahui koneksi matematis pada konsep permintaan dan penawaran.

\section{METODE PENELITIAN}

Penelitian ini merupakan penelitian eksploratif. Penelitian ini dilakukan untuk mengetahui koneksi konsep-konsep matematika dengan konsep permintaan dan penawaran. Pada mata pelajaran ekonomi di kelas $X$, permintaan dan penawaran secara matematis dinyatakan dalam fungsi permintaan dan fungsi penawaran. Penelitian ini mengoneksikan fungsi permintaan dan fungsi penawaran dengan konsep persamaan dua variabel dan fungsi linear. Pendekatan untuk membangun fungsi permintaan dan penawaran dengan persamaan linear dua variabel menggunakan langkahlangkah: 1) menggunakan data banyaknya permintaan, banyaknya penawaran dan tingkat harga dalam bentuk tabel; 2) menentukan variabel; 3) merepresentasikan data dalam bentuk grafik; 4) menentukan persamaan linear dua variabel dengan berbagai metode. Pendekatan untuk membangun fungsi permintaan dan penawaran dengan fungsi linear menggunakan langkah-langkah: 1) menggunakan data banyaknya permintaan, banyaknya penawaran dan tingkat harga dalam bentuk tabel; 2) menentukan himpunan dan hasil kali cartesius; 3) merepresentasikan data dalam bentuk grafik; 4) menentukan fungsi linear dengan menggunakan nilai-nilai fungsi dari data yang diketahui. Eksplorasi juga dilakukan untuk menggali ide-ide matematika yang mungkin muncul dari konsep permintaan dan penawaran seperti yang terdapat dalam buku Nurcahyaningtyas. (2009).

\section{HASIL DAN PEMBAHASAN}

\section{Koneksi Matematis dengan Konsep Permintaan}

Hukum permintaan berbunyi: "jika harga suatu barang naik, jumlah barang yang diminta per unit waktu akan turun. Begitu sebaliknya, jika harga barang turun, jumlah barang yang diminta per unit waktu akan naik." (Widjajanta dan Widyaningsih, 2009 ). Tabel 1 berikut menyajikan contoh banyaknya permintaan pasar dan harga suatu barang yang merepresentasikan hukum permintaan.

Tabel 1. Permintaan Pasar Barang $X$ pada Berbagai Tingkat Harga

\begin{tabular}{cc}
\hline Harga Barang $(\boldsymbol{P})$ & Banyaknya Permintaan $(\boldsymbol{Q})$ \\
\hline 50000 & 100 \\
40000 & 200 \\
30000 & 300 \\
20000 & 400 \\
10000 & 500 \\
\hline
\end{tabular}

Data pada Tabel 1 dapat direpresentasikan dalam bentuk grafik (dengan koordinat cartesius). Kita dapat mengoneksikannya dengan pengetahuan tentang koordinat cartesius yang dipelajari di sekolah menengah pertama (SMP) kelas 7. Sistem koordinat cartesius terdiri dari garis mendatar (sumbu $X$ ) dan garis tegak (sumbu $Y$ ). Letak suatu titik pada koordinat cartesius diwakili oleh pasangan titik $(x, y)$ dengan $x$ absis dan $y$ ordinat (Nuharini dan Wahyuni, 2008). Dalam kasus ini kita dapat membuat koordinat cartesius dengan sumbu mendatar (sumbu $P$ ) dan sumbu tegak (sumbu Q). Pasangan titik-titik $(p, q)$ terdiri dari lima pasang titik seperti pada Gambar 1 berikut.

Cara sitasi: Fatimah, A. T., Effendi, A., dan Amam, A. 2018. Koneksi Matematis pada Konsep Ekonomi (Permintaan dan Penawaran). Teorema: Teori dan Riset Matematika Vol 2, No 2 (2018). Hal 107-116 


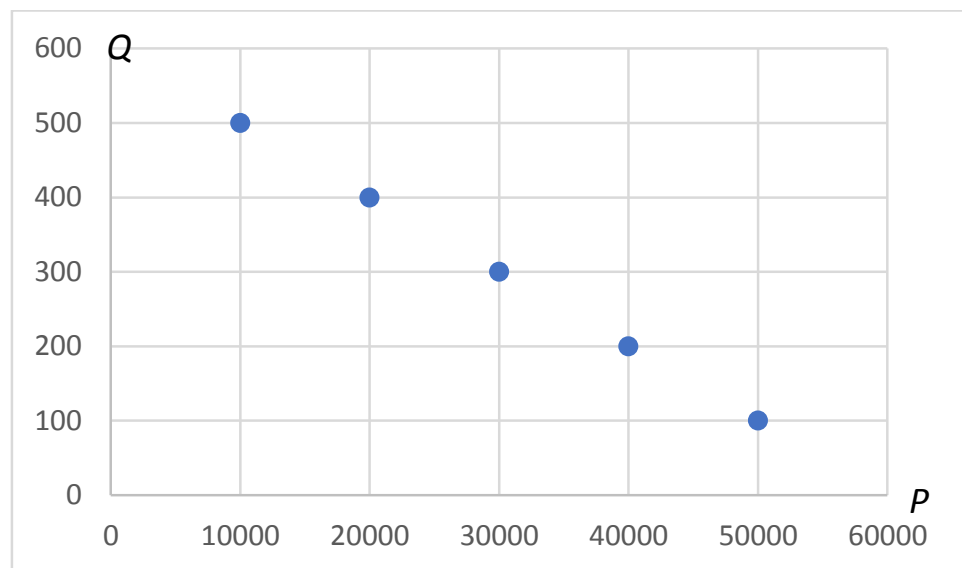

Gambar 1. Koordinat Cartesius Permintaan Pasar Barang X pada Berbagai Tingkat Harga

Perhatikan Gambar 1. Jika titik-titik data tersebut dihubungkan maka akan membentuk garis lurus menurun dari arah kiri atas ke kanan bawah. Hal tersebut sesuai dengan hukum permintaan.

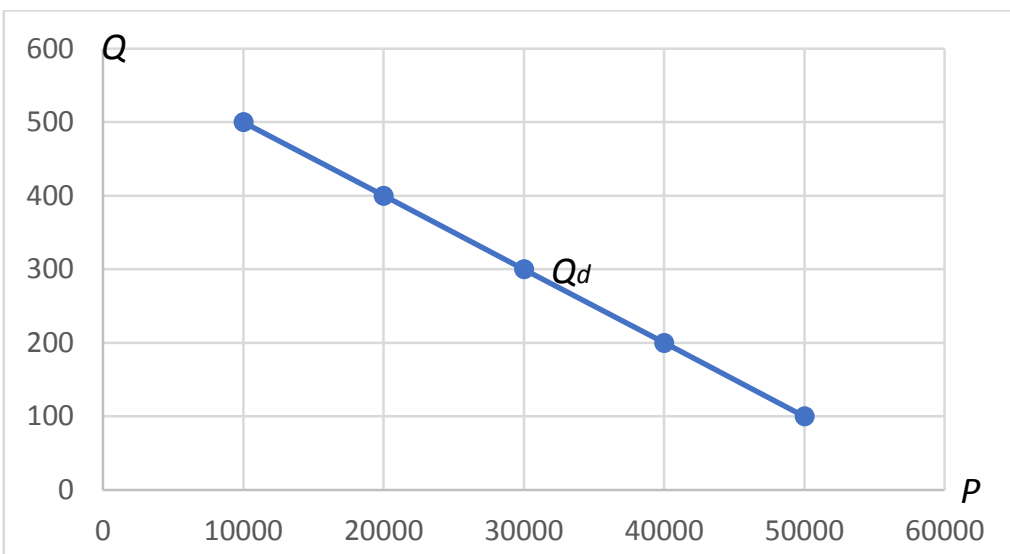

\section{Gambar 2. Kurva Linear Permintaan Pasar Barang $X$ pada Berbagai Tingkat Harga}

Berdasarkan titik-titik data tersebut kita dapat mengetahui persamaan garis lurus (persamaan linear dua variabel) yang telah dipelajari di SMP dan biasa ditulis:

$$
y=m x+c
$$

Karena permintaan bergantung dari harga, maka yang menjadi variabel bebas adalah harga $(p)$ dan variabel terikat adalah banyaknya permintaan $(q)$. Sehingga persamaan (1) ditulis:

$$
q=m p+c
$$

Untuk mendapatkan persamaan linear dua variabel (2) tersebut dapat digunakan konsep matematika yang telah dipelajari di SMP yaitu menyatakan persamaan garis lurus jika grafiknya diketahui atau titik-titik datanya diketahui dengan menggunakan formula-formula berikut:

1) Persamaan garis yang melalui suatu titik $\left(p_{1}, q_{1}\right)$ dan bergradien $m$ adalah

$$
q-q_{1}=m\left(p-p_{1}\right)
$$

2) Persamaan garis yang melalui dua titik sebarang $\left(p_{1}, q_{1}\right)$ dan $\left(p_{2}, q_{2}\right)$ adalah

$$
\frac{q-q_{1}}{q_{2}-q_{1}}=\frac{p-p_{1}}{p_{2}-p_{1}}
$$

Cara sitasi: Fatimah, A. T., Effendi, A., dan Amam, A. 2018. Koneksi Matematis pada Konsep Ekonomi (Permintaan dan Penawaran). Teorema: Teori dan Riset Matematika Vol 2, No 2 (2018). Hal 107-116 
Persamaan permintaan dari Tabel 1 dapat ditentukan dengan persamaan (3) atau (4) dan menghasilkan persamaan,

$$
q=600-\frac{1}{100} p
$$

Berdasarkan hukum permintaan dan karena gradien persamaan garis lurus bertanda negatif, maka persamaan permintaan secara matematis dapat dinyatakan sebagai

$$
q=a-b p
$$

Selain dinyatakan dengan persamaan, secara matematis konsep permintaan sering dinyatakan sebagai fungsi permintaan. Untuk memperoleh fungsi permintaan, dapat dilakukan dengan pendekatan konsep himpunan. Dari Tabel 1 , terdapat dua himpunan yaitu himpunan $P=$ himpunan harga barang dan $Q=$ banyaknya permintaan, ditulis:

$$
P=\{50000,40000,30000,20000,10000\} \text { dan } Q=\{100,200,300,400,500\} .
$$

Berdasarkan definisi hasil kali cartesius dari $Q$ dan $P$ diperoleh,

$$
P \times Q=\{(50000,100),(40000,200),(30000,300),(20000,400),(10000,500)\} \text {. }
$$

Karena setiap anggota $P$ mempunyai pasangan di $Q$ dan setiap anggota $P$ dipasangkan dengan tepat satu anggota $Q$, maka hasil kali cartesius dari $P$ dan $Q$ tersebut disebut dengan fungsi. Dalam kasus ini disebut fungsi permintaan yang dilambangkan dengan $Q_{d}$.

Berdasarkan Gambar 1, jika pasangan hasil kali cartesius dihubungkan maka terbentuk kurva linear sehingga dapat menghasilkan fungsi linear. Misalkan fungsi tersebut adalah

$$
Q_{d}=f(P)=b P+a \text {. }
$$

Nilai $a$ dan $b$, dapat ditentukan dengan konsep sistem persamaan linear dua variabel dari nilai-nilai fungsi. Misal dipilih Jika $P=10000$ maka $f(P)=500$ dan jika $P=30000$ maka $f(P)=300$, ditulis:

$$
\left\{\begin{array}{l}
500=10000 b+a \\
300=30000 b+a
\end{array}\right.
$$

Kita dapat menyelesaikan persamaan (9) dengan menggunakan berbagai metode yang dipelajari di SMP atau SMA, antara lain adalah metode grafik, eliminasi, substitusi, campuran (eliminasi-substitusi), atau matriks sehingga diperoleh nilai $a=600$ dan $b=-\frac{1}{100}$.

Berdasarkan hukum permintaan, maka nilai $b$ akan selalu menghasilkan nilai negatif, sehingga secara umum, fungsi permintaan dinyatakan dengan

$$
Q_{d}=f(P)=a-b P
$$

\section{Koneksi Matematis dengan Konsep Penawaran}

Hukum permintaan berbunyi: "jika harga suatu barang naik, jumlah barang yang ditawarkan per unit waktu akan bertambah. Begitu sebaliknya, jika harga barang turun, jumlah barang yang ditawarkan per unit waktu akan turun." (Widjajanta dan Widyaningsih, 2009). Tabel 2 berikut menyajikan contoh banyaknya permintaan pasar dan harga suatu barang yang merepresentasikan hukum penawaran.

Data pada Tabel 2 dapat direpresentasikan dalam bentuk visual (grafik) seperti pada Gambar 3 berikut.

Cara sitasi: Fatimah, A. T., Effendi, A., dan Amam, A. 2018. Koneksi Matematis pada Konsep Ekonomi (Permintaan dan Penawaran). Teorema: Teori dan Riset Matematika Vol 2, No 2 (2018). Hal 107-116 
Tabel 2. Penawaran Barang $Y$ pada Berbagai Tingkat Harga

\begin{tabular}{cc}
\hline Harga Barang $(P)$ & Banyaknya Penawaran $(Q)$ \\
\hline 50000 & 500 \\
40000 & 450 \\
30000 & 400 \\
20000 & 350 \\
10000 & 300 \\
\hline
\end{tabular}
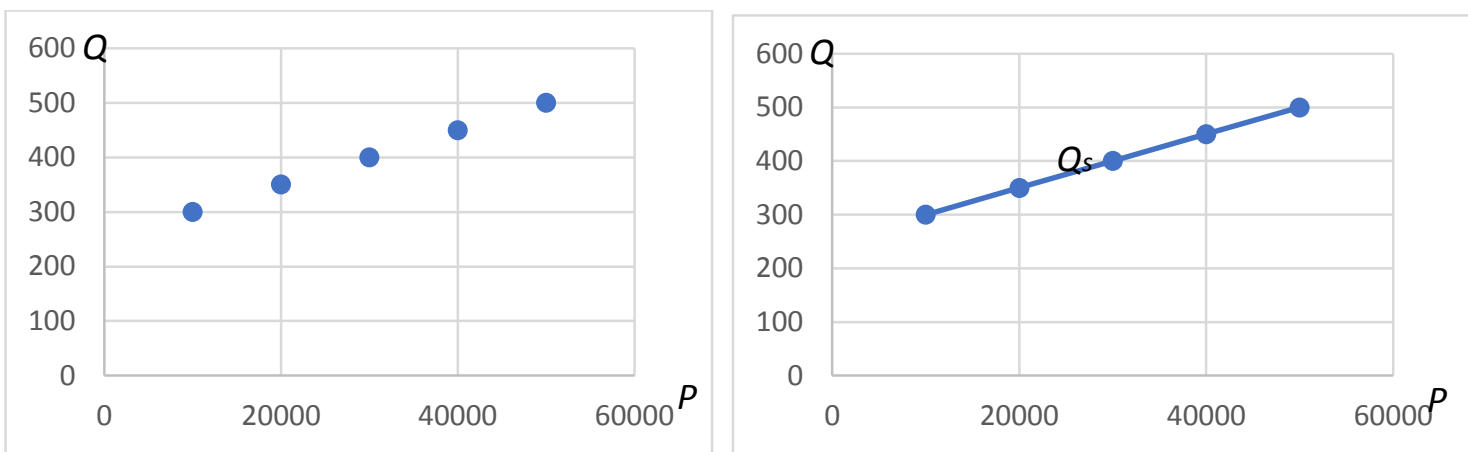

Gambar 3. Grafik Penawaran Barang $X$ pada Berbagai Tingkat Harga

Jika kita memperhatikan gambar 3, maka terlihat kurva yang terbentuk adalah garis lurus (linear) yang bergerak dari bawah kiri ke kanan atas (naik). Hal tersebut sesuai dengan hukum penawaran. Karena kurva tersebut membentuk garis lurus, maka persamaan garis lurus dapat diperoleh dengan cara yang sama seperti pada persamaan permintaan.

Persamaan penawaran dari data Tabel 2 dapat ditentukan dengan persaman (3) atau (4) dan menghasilkan persamaan penawaran,

$$
q=250+\frac{1}{200} p
$$

Berdasarkan hukum penawaran dan karena gradien persamaan linear dua variabel bertanda positif, maka persamaan permintaan secara matematis dapat dinyatakan sebagai

$$
q=a+b p
$$

Selanjutnya, untuk memperoleh fungsi penawaran dengan pendekatan konsep himpunan dapat dilakukan dengan cara yang sama seperti pada fungsi permintaan. Fungsi penawaran dilambangkan dengan $Q_{s}$.

Berdasarkan Gambar 3, jika pasangan hasil kali cartesius dihubungkan maka terbentuk kurva linear sehingga dapat menghasilkan fungsi linear. Misalkan fungsi tersebut adalah

$$
f(P)=b P+a \text {. }
$$

Nilai $a$ dan $b$, dapat ditentukan dengan konsep sistem persamaan linear dua variabel dari nilai-nilai fungsi. Misal dipilih $f(40000)=450$ dan jika $f(20000)=350$, ditulis:

$$
\left\{\begin{array}{l}
450=40000 b+a \\
350=20000 b+a
\end{array}\right.
$$

Cara sitasi: Fatimah, A. T., Effendi, A., dan Amam, A. 2018. Koneksi Matematis pada Konsep Ekonomi (Permintaan dan Penawaran). Teorema: Teori dan Riset Matematika Vol 2, No 2 (2018). Hal 107-116 
Untuk menyelesaikan sistem persamaan (10) dapat digunakan salah satu metode: grafik, eliminasi, substitusi, campuran (eliminasi-substitusi), atau matriks sehingga diperoleh,

$$
a=250 \text { dan } b=\frac{1}{200} \text {. }
$$

Berdasarkan hukum penawaran, nilai $b$ akan selalu menghasilkan nilai positif, sehingga secara umum, fungsi permintaan dinyatakan dengan,

$$
Q_{s}=f(P)=a+b P
$$

Kenyataannya tidak semua data permintaan dan penawaran jika direpresentasikan ke dalam bentuk grafik akan terhubung secara linear. Misalkan diberikan data pada Tabel 2 yang digambarkan pada grafik berikut.

Tabel 3. Permintaan Pasar Barang Z pada Berbagai Tingkat Harga

\begin{tabular}{cc}
\hline Harga Barang $(P)$ & Banyaknya Permintaan $(Q)$ \\
\hline 50000 & 50 \\
45000 & 75 \\
40000 & 100 \\
35000 & 175 \\
30000 & 250 \\
\hline
\end{tabular}

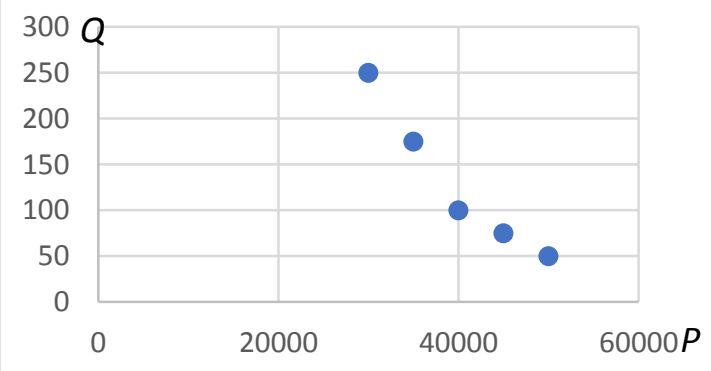

(a)

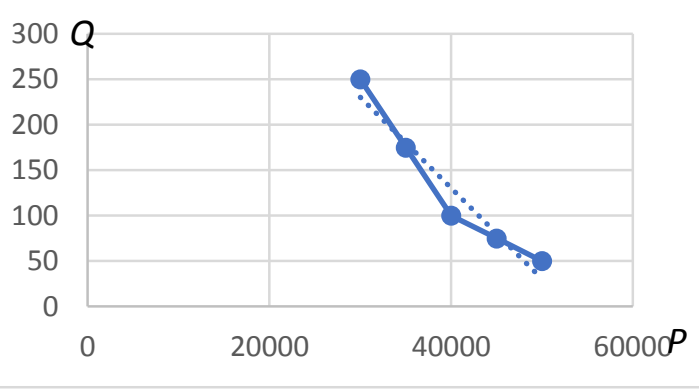

(b)

Gambar 4. Grafik Permintaan Pasar Barang Z pada Berbagai Tingkat Harga

Untuk mendapatkan persamaan linear dua variabel atau fungsi linear seperti pada Gambar 4 yang dinyatakan dengan garis terputus-putus dapat menggunakan berbagai metode fitting curve. Metodemetode tersebut digunakan untuk mencari sebuah fungsi terbaik yang mendekati setiap titik-titik data. Metode yang sering digunakan adalah metode kuadrat terkecil. Persamaan linear dua variabel dari Gambar $4\left(\right.$ b) yang digambarkan dalam garis terputus-putus adalah $Q_{d}=530-\frac{1}{100} p$. Tetapi, metode tersebut tidak diberikan di tingkat sekolah menengah.

Ide matematika yang dapat dimunculkan di sekolah menengah atas dari permasalahan fungsi permintaan dan penawaran seperti pada Tabel 3 adalah konsep peluang yang dikoneksikan dengan konsep persamaan garis lurus. Berdasarkan sifat garis lurus, bahwa sebuah garis lurus dapat terbentuk dari minimal dua titik. Karena terdapat lima titik data, maka akan terbentuk kombinasi dua unsur dari lima unsur dan dapat dinyatakan dengan lambang,

Cara sitasi: Fatimah, A. T., Effendi, A., dan Amam, A. 2018. Koneksi Matematis pada Konsep Ekonomi (Permintaan dan Penawaran). Teorema: Teori dan Riset Matematika Vol 2, No 2 (2018). Hal 107-116 


$$
{ }_{5} C_{2}=\frac{5 !}{2 !(5-2) !}=10
$$

Artinya terdapat sepuluh kemungkinan garis lurus yang dapat dibentuk dari titik-titik data pada Tabel 3 yang digambarkan dalam Gambar 5 berikut.

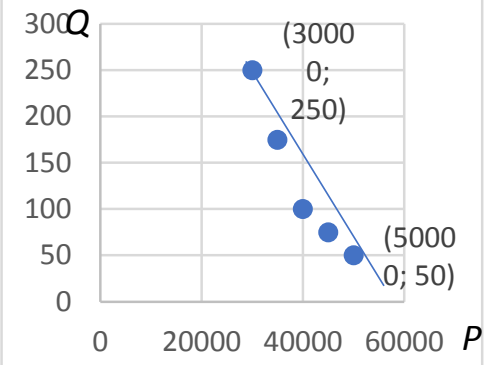

(a)

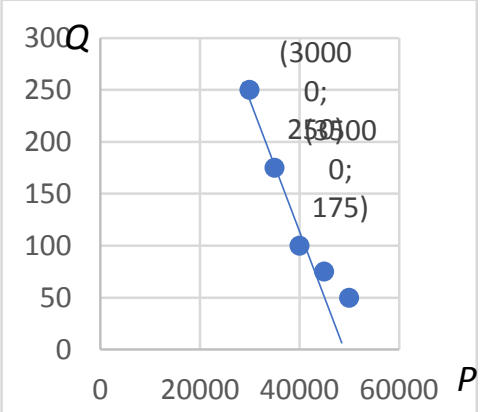

(d)

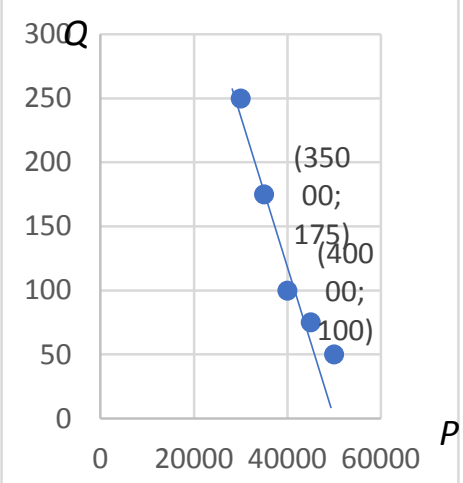

(g)

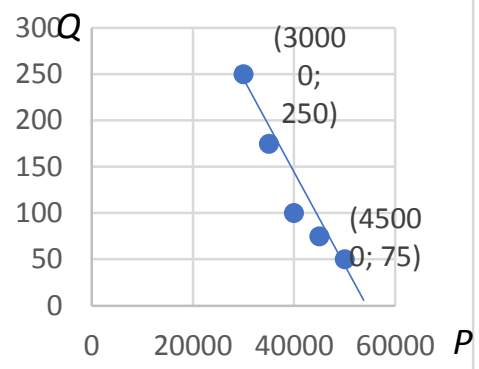

(b)

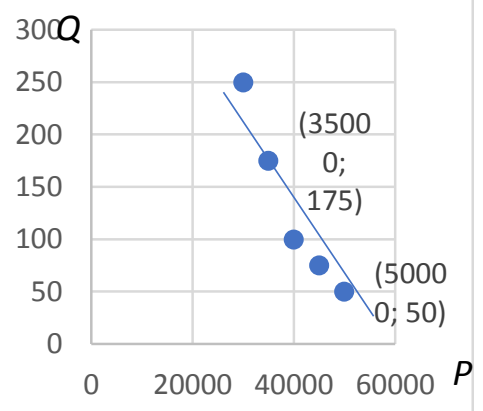

(e)

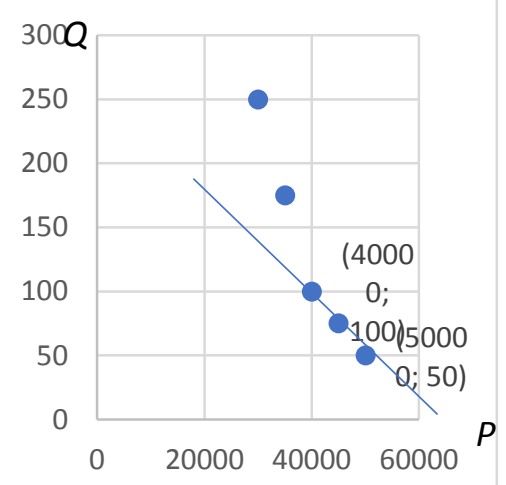

(h)

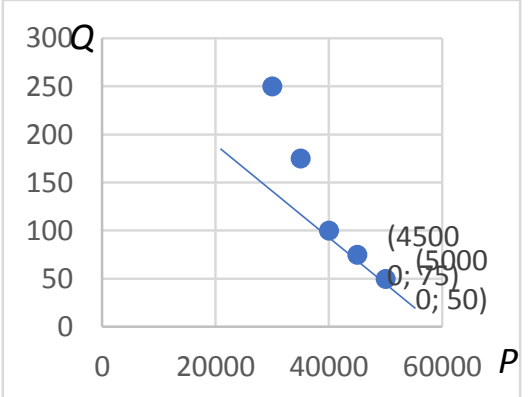

(j)

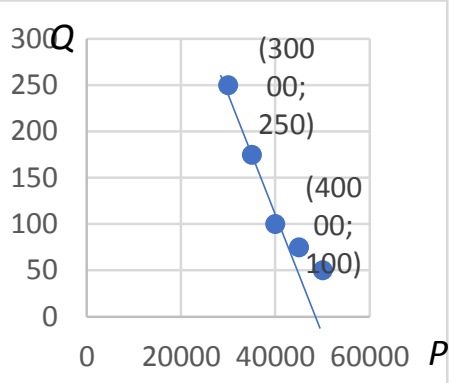

(c)

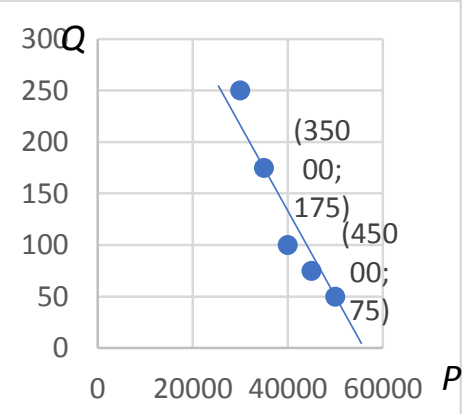

(f)

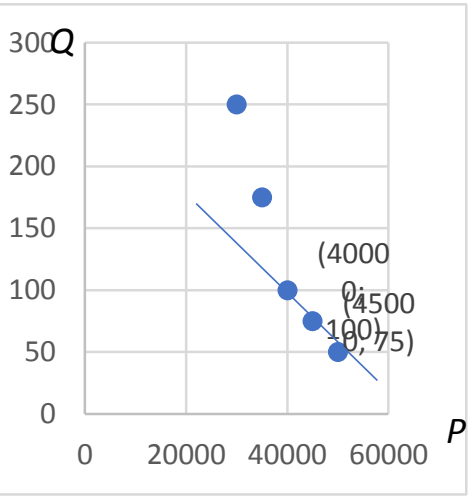

(i)

\section{Gambar 5. Kurva Permintaan Pasar Barang Z pada Berbagai Tingkat Harga yang Dibentuk dari Dua Titik}

Cara sitasi: Fatimah, A. T., Effendi, A., dan Amam, A. 2018. Koneksi Matematis pada Konsep Ekonomi (Permintaan dan Penawaran). Teorema: Teori dan Riset Matematika Vol 2, No 2 (2018). Hal 107-116 
Dengan menggunakan persamaan (3) atau (4) diperoleh sepuluh persamaan garis lurus sebagai berikut: (a) $q=550-\frac{p}{100}$, (b) $q=600-\frac{7 p}{600}$; (c) $q=700-\frac{3 p}{200}$; (d) $q=700-\frac{3 p}{200}$;

(e) $q=\frac{1400}{3}-\frac{p}{120}$; (f) $q=525-\frac{p}{100}$; (g) $q=700-\frac{3 p}{200}$; (h) $q=300-\frac{p}{200}$;

(i) $q=300-\frac{p}{200}$; (j) $q=300-\frac{p}{200}$.

Konsep matematika lain yang dapat memunculkan ide matematika dari konsep permintaan dan penawaran adalah sistem persamaan linear dua variabel seperti pada sistem persamaan (14). Selain itu, harga dan banyaknya suatu barang yang diperjualbelikan dapat ditentukan dengan melihat keseimbangan antara permintaan dan penawaran di suatu pasar. Misalkan diberikan persamaan permintaan dan penawaran berturut-turut berikut ini.

$$
\left\{\begin{array}{l}
q=200-4 p \\
q=100+4 p
\end{array}(19)\right.
$$

Sistem persamaan (19) dapat diselesaikan sehingga diperoleh harga pasar dan nilai keseimbangan permintaan dan penawaran. Dalam masalah ini, terdapat koneksi antara ide matematika untuk menyelesaikannya. Sistem persamaan (19) berkoneksi dengan grafik sistem persamaan. Dalam buku ekonomi (Eko, 2009), peserta didik ditugaskan untuk menggambar suatu kurva keseimbangan. Matematika, sebagai pelayan ilmu, harus dapat melayaninya sehingga peserta didik dapat membuat kurva tersebut. Sistem persamaan (19) dapat direpresentasikan dalam bentuk gambar berikut.

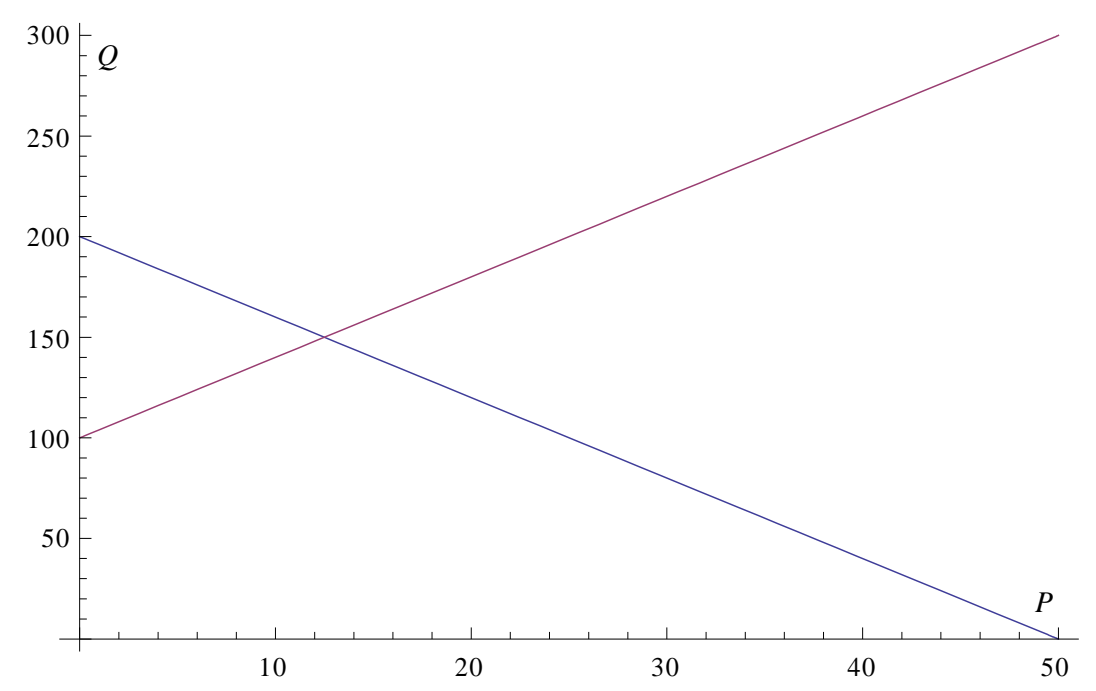

Gambar 6. Kurva Keseimbangan Permintaan dan Penawaran

Untuk mengetahui harga dan nilai keseimbangan permintaan dan penawaran dapat digunakan metode eliminasi, substitusi, eliminasi-substitusi, atau matriks. Diperoleh harga dan nilai keseimbangannya berturut-turut adalah 12,5 dan 250 . Pemilihan metode tentunya didasarkan pada topik materi yang sedang dipelajari sehingga koneksi matematis pada konsep permintaan dan penawaran akan terus tereksplorasi.

Cara sitasi: Fatimah, A. T., Effendi, A., dan Amam, A. 2018. Koneksi Matematis pada Konsep Ekonomi (Permintaan dan Penawaran). Teorema: Teori dan Riset Matematika Vol 2, No 2 (2018). Hal 107-116 


\section{KESIMPULAN}

Koneksi matematis dengan konsep permintaan dan penawaran adalah terbangunnya fungsi permintaan dan fungsi penawaran. Dalam membangun fungsi permintaan dan penawaran terdapat koneksi antar ide/konsep matematika, yaitu: merepresentasikan data numerik menjadi grafik (dengan koordinat cartesius), menentukan persamaan linear dua variabel dengan cara menentukan garis lurus jika diketahui gradien dan satu titik data atau menentukan garis lurus dari dua titik data, serta menentukan fungsi linear dari nilai-nilai fungsi.

Banyak manfaat yang dapat diperoleh dengan mengetahui koneksi matematis pada konsep permintaan dan penawaran bagi pengajar dan peserta didik. Pengajar matematika dapat memunculkan masalah permintaan dan penawaran dalam proses pembelajaran terutama pada kelas peminatan ilmu sosial atau kepada peserta didik yang memiliki minat terhadap bidang ekonomi. Bagi peserta didik, dengan mengetahui koneksi matematis, dapat mengetahui manfaat mempelajari matematika sehingga tidak menganggap matematika hanya sekedar konsep yang dipelajari secara parsial.

\section{REKOMENDASI}

Masalah permintaan dan penawaran juga dapat dikoneksikan pada konsep peluang dan sistem persamaan linear dua variabel. Eksplorasi pemanfaatan konsep permintaan dan penawaran untuk membangun konsep matematika dan sebaliknya, perlu terus dilakukan.

\section{UCAPAN TERIMAKASIH}

Ucapan terima kasih kami sampaikan pada semua pihak yang telang berkontribusi dalam penelitian ini baik langsung maupun tidak langsung. Terutama kepada:

1. Prodi pendidikan matematika UNIGAL

2. LPPM Universitas Galuh

3. Jurnal Teorema yang bersedia mempublikasi artikel ini

\section{DAFTAR RUJUKAN}

Afgani, J.D. (2011). Analisis Kurikulum Matematika. Jakarta: Universitas Terbuka.

Bailey, et al. (2006). Mathematics Aplications and Concepts. USA: The McGraw-Hill Companies.

Eko, Y. (2009). Ekonomi untuk SMA dan MA Kelas X. Jakarta: Pusat Perbukuan Departemen Pendidikan Nasional.

NCTM. (2000). Principles and Standards for School Mathematics. USA.

Nurcahyaningtyas. (2009). Ekonomi untuk Kelas X SMA/MA. Jakarta: Pusat Perbukuan Departemen Pendidikan Nasional.

Nurharini, D., \& Wahyuni, T. (2008). Matematika Konsep dan Aplikasi. Jakarta: Pusat.

Peneltian, B., \& Pendidikan, P. K. Kebudayaan (Balitbang Kemendikbud). 2016. Survey Internasional PISA.

Widjajanta, B. dan Widyaningsih, A. (2009). Mengasah Kemampuan Ekonomi untuk Kelas X Sekolah Menengah Atas dan Madrasah Aliyah. Jakarta: Pusat Perbukuan Departemen Pendidikan Nasional.

Cara sitasi: Fatimah, A. T., Effendi, A., dan Amam, A. 2018. Koneksi Matematis pada Konsep Ekonomi (Permintaan dan Penawaran). Teorema: Teori dan Riset Matematika Vol 2, No 2 (2018). Hal 107-116 